\title{
Tulane
}

Tulane Economics Working Paper Series

\section{What Drives State Tax Reforms?}

\author{
James Alm \\ Department of Economics \\ Tulane University \\ jalm@tulane.edu
}

\author{
Trey Dronyk-Trosper \\ Department of Economics \\ Tulane University \\ rtrosper@tulane.edu
}

\author{
Steven M. Sheffrin \\ Department of Economics \\ Tulane University \\ smsheffrin@tulane.edu
}

Working Paper 1621

December 2016

\begin{abstract}
This paper discusses recent trends in state (and local) taxation, examines the prospects for reform of state tax systems, and analyzes a wide range of issues that relate to ongoing state efforts to reform their tax systems.
\end{abstract}

Keywords: Tax reform, Schanz-Haig-Simons taxation.

JEL codes: H2, H7 


\title{
What DRIVES STATE TAX REFORMS?
}

\author{
James Alm (jalm@tulane.edu) \\ Trey Dronyk-Trosper ( $\underline{\text { rtrosper@tulane.edu })}$ \\ Steven M. Sheffrin (smsheffrin@tulane.edu)
}

\begin{abstract}
This paper discusses recent trends in state (and local) taxation, examines the prospects for reform of state tax systems, and analyzes a wide range of issues that relate to ongoing state efforts to reform their tax systems.
\end{abstract}

Keywords: Tax reform, Schanz-Haig-Simons taxation.

JEL Classifications: H2, H7.

When people think of "tax reform", the vision that most often comes to mind is the 1986 federal tax reform. The Tax Reform Act of 1986 (TRA86) was the classic image of a tax reform, as it conformed to the economist mantra of a "broad-base, low rate" reform, often referred to as the Schanz-Haig-Simons view of (income) taxation. ${ }^{1}$ Economic theory does not dictate precisely this mantra, but it has been largely endorsed as moving taxes in the right direction. A broad-base, low-rate tax system is of course better at generating larger amounts of revenue than tax systems with a narrower base, thereby achieving the goal of adequacy. It is seen as being fair because all types of income, whatever their source, are taxed equally. It is also efficient because there are no incentives to shift income toward less heavily taxed sources, so that the distorting effects of taxation are minimized; also, a broad base reduces the tax rate that must be imposed to generate a given level of revenues, which also reduces the distorting effects of taxation. 
The few current U.S. efforts at federal government tax reform today also emphasize lower rates. However, the focus of lower tax rates has largely shifted away from individual income tax rates toward corporate rates, which at 35 percent are among the highest rates in the world. Base broadening via the elimination or the reduction of the many tax preferences in the federal tax code is often mentioned, but it receives far less attention than 30 years ago. Indeed, there seems to be less discussion of broadening the existing income tax base and more discussion of a fundamental change in the tax base, from income to consumption.

In contrast, $\underline{\text { state }}$ government tax reforms do not easily fall into this vision of broad-base, low-rate reform. Even so, states have often energetically pursued various tax reform efforts. Indeed, since 2000 there have been major tax reform efforts in at least 27 states, as well as in the District of Columbia, some prompted largely in response to the immense fiscal pressures unleashed by the "Great Recession" of 2007-2008 and many stemming from the recognition that the current tax system no longer meets current demands. ${ }^{2}$

However, our understanding of what drives state tax reforms - as well as our understanding of what are the effects of these reforms - is grossly inadequate. In response to these challenges, the Murphy Institute and the Department of Economics at Tulane University sponsored a conference in October 2015 that explored recent developments in state and local tax reforms, "Reforming State and Local Tax Systems". The articles in this special issue of Public Finance Review explore a wide range of issues that relate to ongoing state efforts to reform their tax systems.

Earlier versions of most of these papers were presented at the October 2015 conference. The articles were submitted to Public Finance Review without any guarantee of publication, 
went through the regular reviewing process, and were revised in response to comments by the anonymous, external reviewers.

In this introduction, we provide the broad context within which ongoing state tax reform efforts are occurring, after which we review the articles in this special issue. We finish with some brief conclusions.

The starting point is the broad trends in taxation in the states over the last half-century. These trends in are conveyed in Figures 1 and 2, which show the average level of taxation in the states over the years (Figure 1) and the relative reliance on the major state taxes over the years (Figure 2). These figures indicate that the level of state taxation has risen considerably over the years, from $\$ 82$ per capita in 1934 to $\$ 1034$ per capita in 2013 (in constant 1982-1984 dollars). These figures also indicate that state reliance on general sales taxes has decreased over time, although the importance of the individual income tax has tended to rise over the same period. The use of the corporate income tax is significant, but is considerably smaller than the collection of sales and individual income taxes. The states also make some use of excise taxes, especially gasoline, alcohol, and tobacco, although there are few states that rely heavily on excise taxes. The combination of gasoline, alcohol, and tobacco excise taxes amount to less than 20 percent of sales tax revenue in 36 of the 46 states with general sales taxes.

However, these broad trends mask enormous variation across the states. For example, Figures 3 through 7 show the patterns of taxation in California, Georgia, Michigan, Nebraska, and Utah, respectively. These states are not chosen randomly, but instead reflect states that are examined in the articles in this special issue. Generally speaking, corporate income taxes play the least important role in generating tax revenues in these states. Michigan relies the least on individual income taxes of these states, but leans more heavily on the collection of property taxes 
compared to California, Georgia, Nebraska, and Utah. Notably, none of the five states rely disproportionately on any one single tax instrument.

Louisiana is another state that is of some interest (Figure 8). Louisiana has exempted so much of its property tax base that local governments have been forced to rely on a local sales tax, imposed on a narrow, porous, and complicated tax base with combined state and local tax rates that are the highest in the country. Louisiana also allows a deduction for federal taxes paid for both the individual and corporate income tax, thereby creating a situation where the nominal tax rate exceeds the effective tax rate for many taxpayers. The state also has enacted a huge array of economic incentives all of which combine to reduce state tax collections by nearly the amount of actual state tax collections. Overall, Louisiana via its general sales tax places a higher degree of importance on the collection of single tax revenue streams than most other states.

Many states would clearly benefit from major reforms. Their tax systems are in many cases the relic of older times, ill-designed for the realities of the modern economy. Especially in the last decades, these tax systems have faced increasing challenges, in such areas as the growth of both services and internet sales, increased tax competition, greater factor mobility across state (and national) boundaries, and other similar developments, many of which have made it increasingly difficult for tax systems to generate adequate revenues in an efficient and fair way. These issues are what drive the reform efforts, and in the face of these challenges there have been frequent and varied attempts to reform state tax systems.

These reform efforts have varied considerably, but they have typically emphasized such common themes as: reducing individual income tax brackets and rates and simplifying income taxes; broadening the sales tax base to include services, reducing sales tax rates, and establishing a common state and local sales tax base with uniform definitions of commodities and services 
along the lines of the Streamlined Sales and Use Tax Agreement; and reducing corporate income tax rates and simplifying corporate income taxes. To date, however, few of these reform efforts have actually led to large, comprehensive, and enacted reforms.

As one recent example of a comprehensive tax reform effort, Richardson, Sheffrin, and Alm (2016) recommended multiple changes to Louisiana's tax system, broadly consistent with the broad-base, low-rate strategy. For the individual income tax, they suggested a reduction of marginal tax rates from 2-4-6 percent, to 1-3-5 percent, along with the elimination of federal deductibility and excess itemized deductions and the sunset of a number of tax credits (including many designed for economic development purposes). For the corporate income tax, they recommended a single tax rate of 5 percent, the elimination of federal tax deductibility, a decrease in the generosity of the net operating loss carryback provision, the reconsideration of the state corporate income tax apportionment formula, and a rethinking of the corporate franchise tax. They also recommended a reduction of the state sales tax, achieved via the expansion of the sales tax base to include a range of services and the sunset of several exemptions. An especially important recommendation for the sales tax was a unified state and local sales tax collection and audit process, which would also require some standardization of state and local sales tax bases. These reform suggestions are currently under consideration by a special Task Force appointed by the Governor of Louisiana, John Bell Edwards. Efforts in other states have varied, but many reform efforts share similar themes.

However, most state tax reforms are of a more modest variety. For example, state corporate tax reform has typically focused on providing additional economic incentives for locating in the state by moving to increased weight on the sales factor in apportioning the income of multistate business. This shifts the burden of taxation towards companies that operate out-of- 
state, and provides a tax break for companies operating within the state. In a related move, states have also begun to change the way they calculate the sales factor for services to reach firms that sell services into the state. Finally, states have taken a number of steps to make sure that their tax base is not subject to manipulation through innovative tax structuring by firms. Combined reporting, which severely curbs these tax maneuvers, now is the norm in more than half of the states. A few states have recently adopted all these policies together; for example, Rhode Island has now moved to combined reporting, single sales factor apportionment, and market sourcing for services.

States have also become more aggressive in trying to force out-of-state sellers to collect and remit the use tax for purchases made by consumers in their state, despite U.S. Supreme Court rulings. The latest move by Colorado to require mandatory reporting (both to the purchaser and the state) of all sales has so far survived court challenges, and has forced some large sellers to begin to collect the use tax. Other states, including Louisiana, have recently enacted similar provisions. Several states are also mounting direct challenges to the doctrine in Quill Corporation v. North Dakota, in which the Supreme Court reaffirmed that physical presence was necessary to require out-of-state sellers to collect the use tax. In other actions, beginning in 2010 Texas requested that Amazon remit \$269 million in uncollected sales taxes. By 2012, in exchange for Texas forgiving the uncollected sales taxes, Amazon agreed to invest in the construction of distribution centers in the state. The 2011 passage of Texas H.B. 1 ensured that Amazon would be required to remit sales taxes so long as they had a "nexus" within the state.

Several articles in this special issue examine previous and ongoing efforts at tax reform in specific states. There is also an article that takes a broader perspective, and investigates some general issues in overall state tax reform. 
Gary C. Cornia, R. Bruce Johnson, and Ray D. Nelson outline the major structural tax reform proposed for Utah in 2004 by then-Governor Olene Walker, who recommended several major changes in the state tax system. First, she wanted to extend the sales tax to services, not just personal services, but also medical, legal, and accounting services. She offered this relatively radical scheme despite the ill-fated experience with extending the sales tax to major services in Florida in the late 1980s. Second, she recommended abolishing the corporate tax. Finally, she advocated for a flat rate individual income tax with a complete elimination of all deductions and exemptions. None of these proposals came to fruition. However, Utah's reform did lead to a significant change in the individual income tax. Instead of the initial recommendation of a simple flat rate individual income tax with no deductions or exemptions, the state enacted an income tax that retained exemptions and deductions via a tax credit.

Cornia, Johnson, and Nelson examine one aspect of the recommended and the enacted individual income tax reforms: the volatility of income tax collections. Among the reasons for the initial recommendation for a flat tax with no deductions or exemptions was the argument that it would result in a more stable year-over-year tax revenue stream, which was seen as especially important for education financing. However, the tax system that was enacted retained exemptions and deductions through the use of a tax credit. Using a series of simulations based on 21 years of tax returns, Cornia, Johnson, and Nelson show that the enacted reform failed to reduce the volatility of individual income tax revenues. Their simulations also show that the initially proposed flat income tax with no exemptions or deductions would have decreased volatility, but at the cost of also reducing the growth rate of revenues. Their study demonstrates and quantifies the many tradeoffs that are necessarily involved in any tax reform. 
Andrew Feltenstein, Mark Rider, David L. Sjoquist, and John V. Winters examine a different tax and a different state: the property tax in Georgia. While there is often a sound political and economic rationale for local government reliance on the property tax, there are also some economic drawbacks. While land is immobile and taxing land does not cause excess burdens, the same is not true for the part of the property tax that falls on structures. Under some capital tax views, high property taxes on structures, particularly those of business, have been shown to cause capital flight and economic distortions (Zodrow 2001). Would local governments be better off reducing property taxes and relying more on sales taxes?

This question is explored by Feltenstein, Rider, Sjoquist, and Winters. They consider a specific proposal - and one that has been suggested by various Georgia state legislators - that would reduce by half the property tax on homesteaded properties and replace the lost revenue by increasing the base and rate of the state sales tax. They construct a dynamic computable general equilibrium (CGE) model, calibrate it for Georgia, and then combine it with a detailed microsimulation model (MSM) also calibrated for Georgia in order to examine more fully the distributional impacts of the proposed replacement of the property tax with the state sales tax. The results of the CGE model show that the revenue-neutral reform would have a decidedly negative effect on Georgia's economy. Since the tax reform would consist of a decrease in the tax on capital in a capital-intensive industry (e.g., housing) and an increase in the tax on output in labor-intensive industries, the reform would increase the rental-wage ratio and would also shift labor out of the state. Combined with the dynamic effect on investment in capital, the result would be to reduce the growth in income and consumption. Their MSM results also demonstrate that the reform would have no significant impact on the distribution of consumption by income class but would likely increase owner-occupied housing relative to rental housing. 
John E. Anderson examines a different aspect of sales tax reform: compliance with the state sales and, especially, the use tax. Compliance with the use tax component of the sales tax is notoriously poor (Alm and Melnik 2012). In the face of this non-compliance, several states have added a line to their individual income tax returns on which taxpayers can voluntarily report and pay taxes upon - their taxable sales. Anderson examines the effects of a controlled field experiment in Nebraska that introduced an additional use tax "nudge", in which a postcard was sent to a random sample of income tax filers explicitly telling them about this new use tax reporting line on their tax return. He finds that this informational nudge more than doubled the likelihood of use tax reporting and also nearly doubled the amount of revenue collected. Even so, the rate of use tax reporting and the associated revenue remained quite low. Overall, Anderson concludes that this specific informational nudge had positive impacts, but that by itself it was not sufficient to substantially change use tax compliance.

Still another area that needs careful examination is state taxation of gasoline, especially as fuel efficiency increases, driving patterns change, and gasoline prices fluctuate. This issue is particularly important since the average vehicle-driven mileage has fallen from 13,200 miles in 2005 to 12,000 miles in 2015. Increases in fuel efficiency and reductions in driving distance directly affect state and local fuel-based revenue collections. Ronald C. Fisher and Robert W. Wassmer examine how individual perceptions of gasoline taxes affect support for funding highway improvements, focusing on California and Michigan voters. Using a survey of likely California and Michigan voters, Fisher and Wassmer find that voters often overestimate the rate of their state's gasoline excise tax and the subsequent amount they are likely to pay for this tax in a month. Their regression analyses further shows that voter misperceptions concerning the magnitude of state fuel taxes affect their views regarding an increase in funding to support 
highway investment proposals. Fisher and Wassmer conclude that the adoption of proposals to generate additional funds for highway investment are more likely if accompanied by a campaign identifying the existing rate of the state's gasoline excise tax and the relatively small amount of this tax paid by the state's typical driver. Their findings also raise difficult political questions: How should the public be educated on complex matters when their perceptions differ from actual practice - and indeed should these efforts even be made?

One last article focuses not on a specific state but on broader issues in state tax reform. Many state tax systems provide extremely generous tax breaks for elderly, mainly on the belief that these programs are necessary for distributional equity. Ben Brewer, Karen Smith Conway, and Jonathan C. Rork provide a comprehensive review of current state government practices of tax breaks for the elderly. They use data from the 1990 Integrated Public Use Microdata Series (IPUMS) and the 2013 American Community Survey (ACS), combined with the NBER TAXSIM calculator, to calculate current state income tax liabilities; they also simulate the effects of removing all age-related tax breaks. They find that the economic well-being of the elderly has grown substantially relative to the non-elderly. Importantly, they find that state tax breaks primarily benefit the middle and upper income elderly and that these programs have had only modest, indeed mixed, impacts on income inequality as measured by changes in the Gini coefficient, despite the large and increasing revenue costs of these many elderly tax breaks. Their findings provide a strong basis for concluding that these tax breaks are a relic of our past experience when the elderly were poorer than the rest of society. Brewer, Conway, and Rork show that this is no longer the case, raising doubts that these programs are still needed.

Overall, we believe that these articles demonstrate several major lessons from previous and current efforts at reforming state tax systems. ${ }^{3}$ One lesson is that timing is important. The 
best time for comprehensive reform is often in bad economic times, since this ensures that everyone's attention is focused and that everyone recognizes the necessity of tax reform. The many efforts at state tax reform following the "Great Recession" provide some anecdotal evidence to support this lesson.

A second lesson is that base broadening is often consistent with adequacy, equity, and growth concerns. Base broadening can obviously increase tax revenues. The elimination of tax preferences and more generally the broadening of the tax base can also improve both vertical and horizontal equity by ensuring that the wealthy pay their "fair" share and that equals are treated equally. Finally, base broadening reforms can enhance economic growth by improving efficiency and by reducing the incentives for income shifting activities.

A last lesson is that there is no one-size-fits-all tax reform. Any tax reform must consider the institutions, the traditions, the economic policies, and especially the politics of the current and specific state situation. This means in particular that tax reforms must balance the various tradeoffs that necessarily and inevitably exist between the need to generate revenues but to do so in an efficient and a fair way.

Still, given the track record of most states in actually enacting tax reform, it is hard to avoid some cynicism about these efforts. Indeed, Bourdeaux (2011) has suggested "The Seven Steps of State Tax Reform":

(1) Form a commission

(2) Develop "Principles of Tax Reform"

(3) Hold hearings/review expert testimony/conduct analysis

(4) Make a proposal

- If your state does not have an income tax $\rightarrow$ propose an income tax

- If your state does not have a retail sales/consumption tax $\rightarrow$ propose a sales tax

- If your state has a goods-based retail sales tax $\rightarrow$ propose to tax more services

- If your state has a corporate income tax $\rightarrow$ propose a gross receipts tax

- If your state has a gross receipts tax $\rightarrow$ propose a corporate income tax 
- If your state has any form of business tax $\rightarrow$ propose the elimination of all business taxes

- If your state needs "bold new thinking on taxes" $\rightarrow$ propose a value-added tax

- Propose the elimination of all exemptions, credits, and deductions

- Express frustration that the state cannot effectively tax internet sales

- Optional: Mess with local government revenues

(5) Watch your proposal go down in flames in the political process

(6) Wait 5-10 years until the next fiscal crisis

(7) Repeat.

These "Steps" are clearly intended to be tongue-in-cheek, but they contain some elements of truth. While there are certainly are "tried and true" recommendations, actual reforms necessarily tackle a range of other important issues.

We believe that the articles in this special issue provide many creative insights for the broad outlines - and the specific details - of state tax reform. Further research on many aspects of tax reform is clearly required, and these articles are a useful starting point for what is now required to move forward.

\section{References}

Alm, James and Mikhail I. Melnik. 2012. Cross-border shopping and state use tax liabilities: Evidence from eBay transactions. Public Budgeting \& Finance 32 (1): 5-35.

Alm, James and Steven M. Sheffrin. 2013. Can tax reform solve the "fiscal trilemma"? Public Finance Review 41 (6): 711-720.

Bourdeaux, Carolyn. 2011. A review of state tax reform efforts. Fiscal Research Center Report 216. Atlanta, GA: Andrew Young School of Policy Studies, Georgia State University.

Haig, Robert M. 1921. The concept of income - Economic and legal aspects. In Robert M. Haig (Ed.), The Federal Income Tax. New York, NY: Columbia University Press, 1-28.

Pathak, Rahul, Carolyn Bourdeaux, Sally Wallace, and Sarah Larson. 2016. State tax reform efforts: 2010-2015. Center for State and Local Finance Report, Publication No. 22. Atlanta, GA: Andrew Young School of Policy Studies, Georgia State University.

Richardson, James, Steven M. Sheffrin, and James Alm. 2016. Reforming Louisiana's Tax System. Baton Rouge, LA: Louisiana State University Press.

Schanz, Georg von. 1896. Der einkommensbegriff und die einkommensteuergesetze [Income realized and the income tax law]. FinanzArchiv 13 (1): 1-87.

Simons, Henry. 1938. Personal Income Taxation: The Definition of Income as a Problem of Fiscal Policy. Chicago, IL: University of Chicago Press. 
Zodrow, George R. 2001. The property tax as a capital tax: A room with three views. National Tax Journal 54 (1): 139-156. 
Figure 1. All State Governments - Tax Collections (in constant dollars per capita)

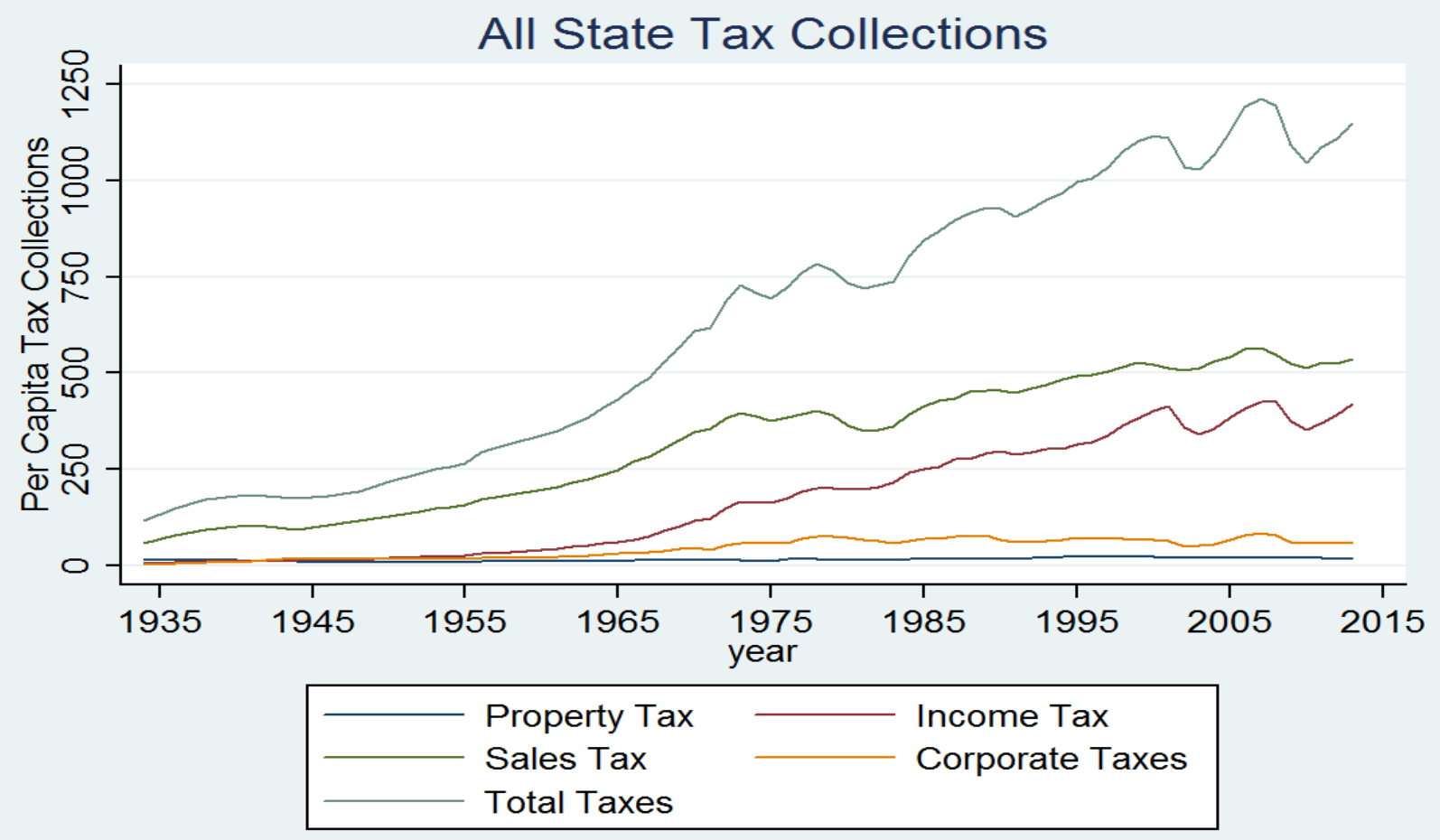

Source: U.S. Census Bureau Survey of State and Local Finances.

Figure 2. All State Governments - Tax Shares (as percent of Total Taxes)

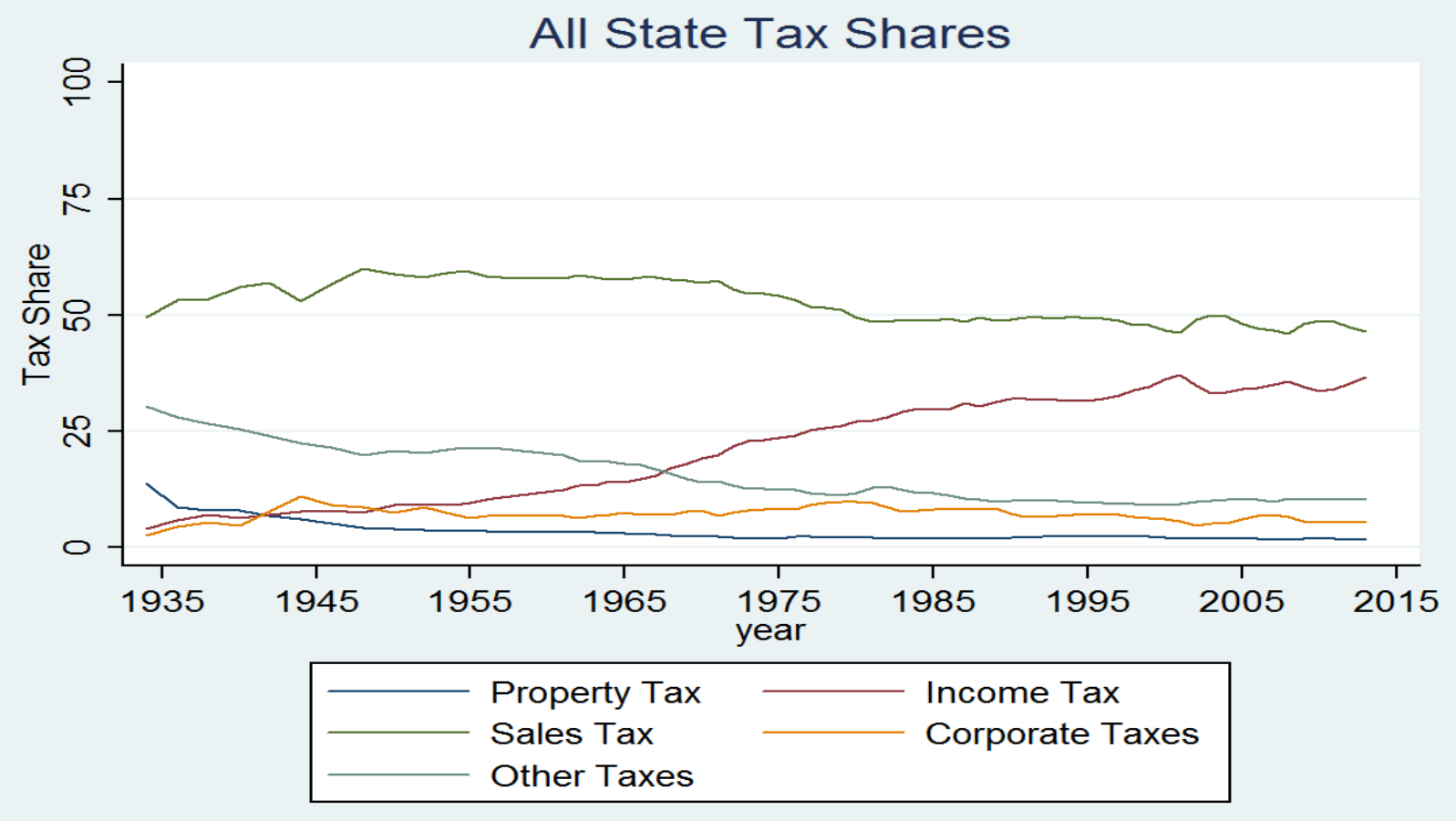

Source: U.S. Census Bureau Survey of State and Local Finances. 
Figure 3. California - Combined State and Local Tax Collections (in constant dollars per capita)

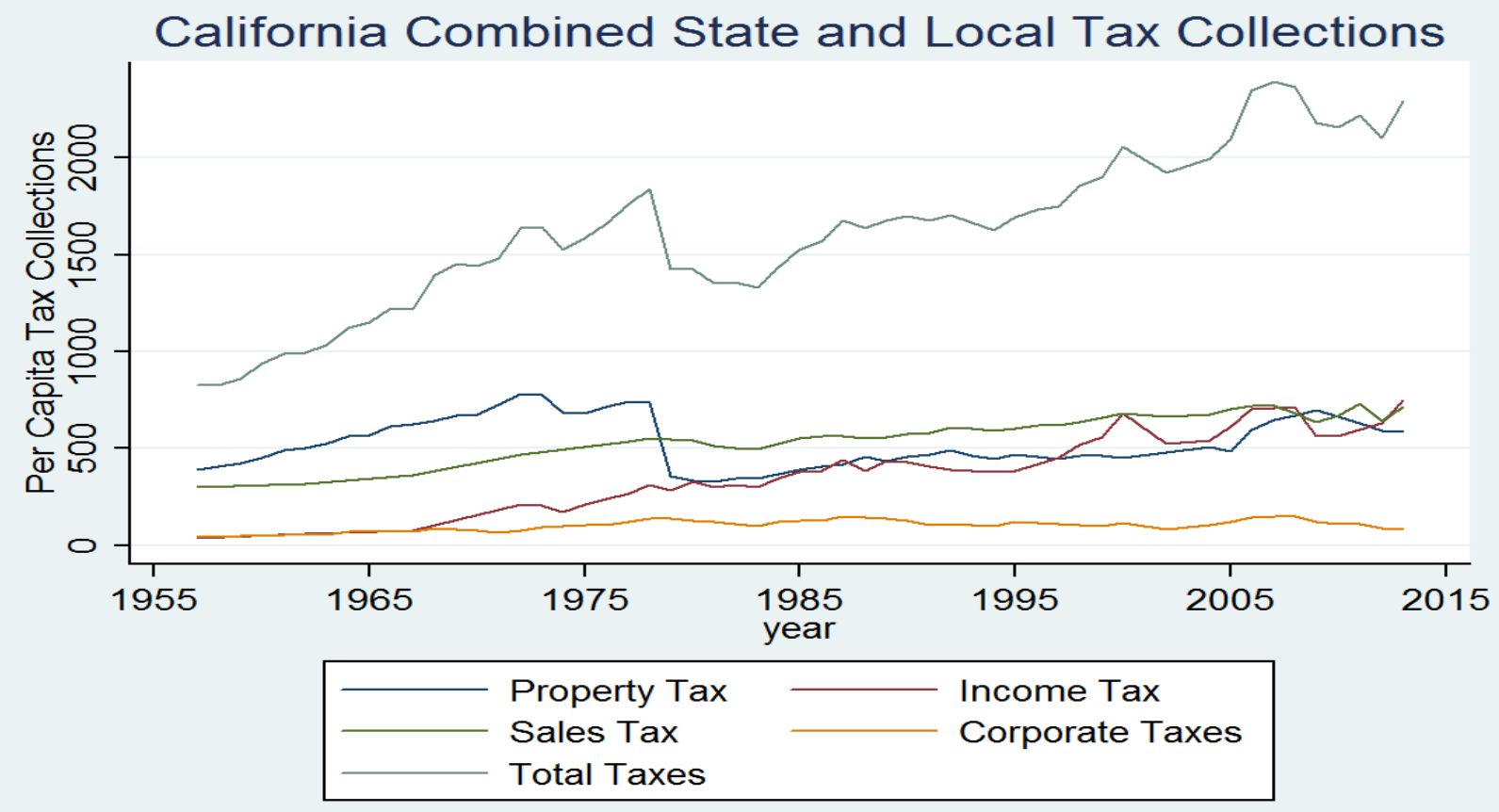

Source: U.S. Census Bureau Survey of State and Local Finances.

Figure 4. Georgia - Combined State and Local Tax Collections (in constant dollars per capita)

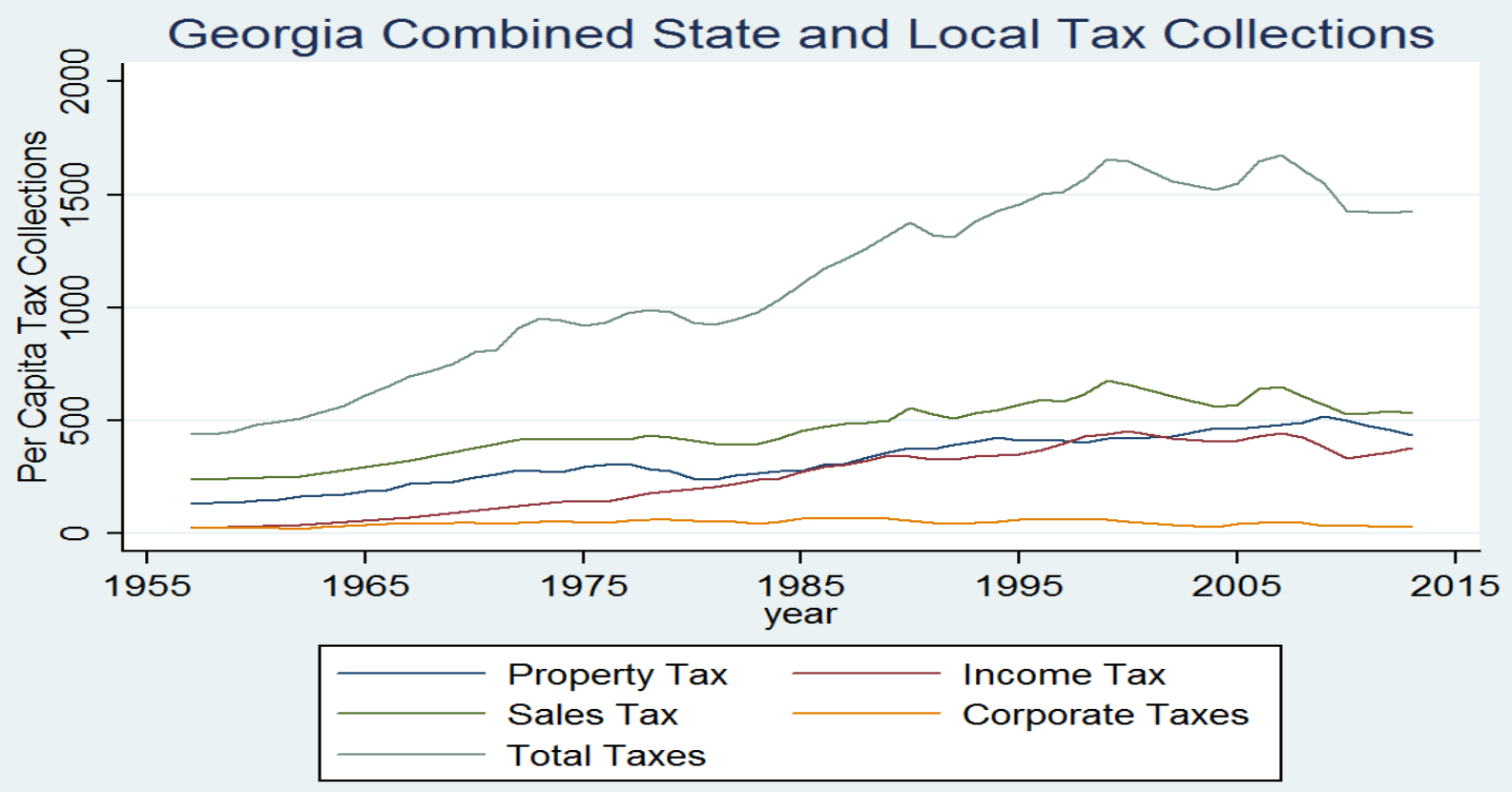

Source: U.S. Census Bureau Survey of State and Local Finances. 
Figure 5. Michigan - Combined State and Local Tax Collections (in constant dollars per capita)

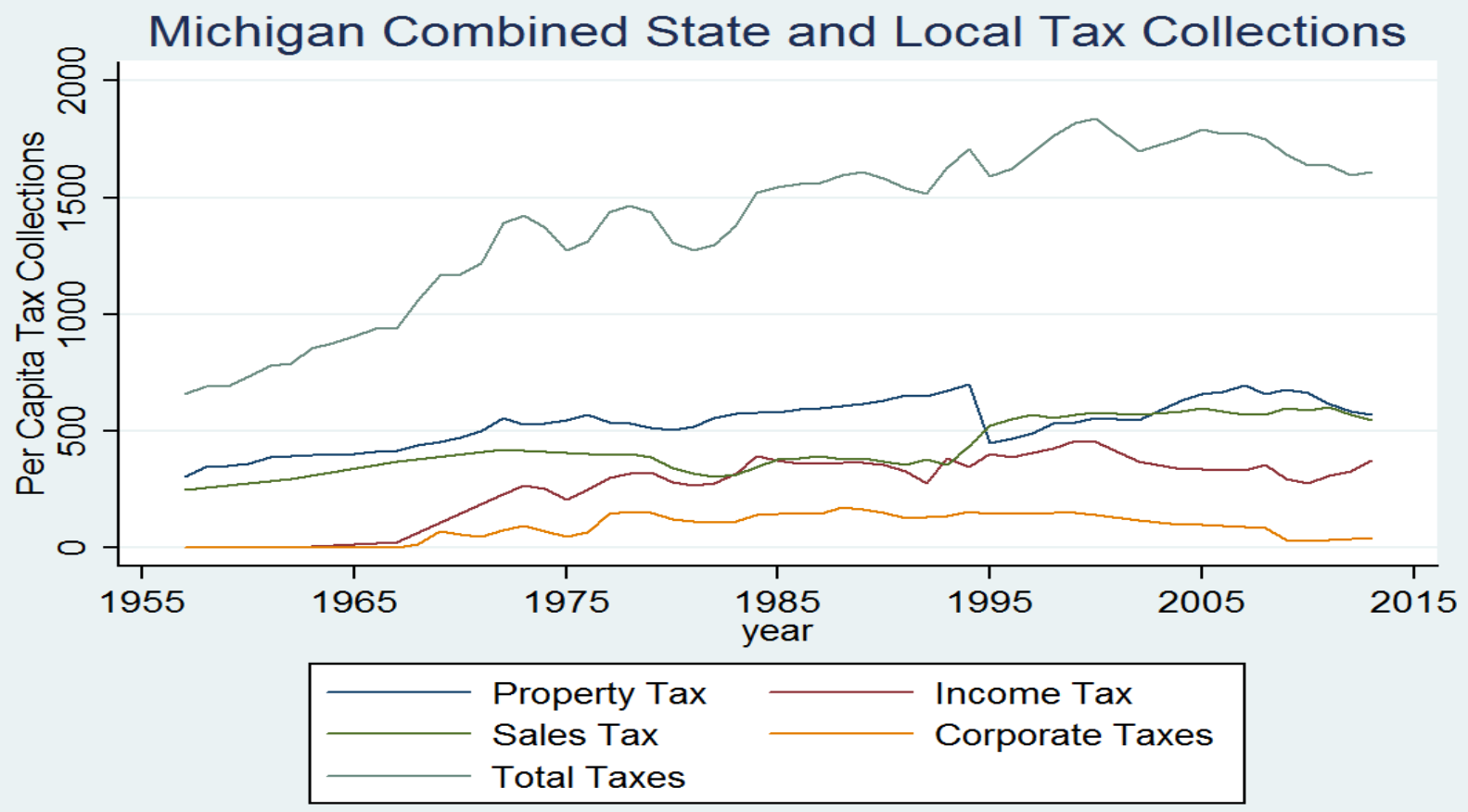

Source: U.S. Census Bureau Survey of State and Local Finances.

Figure 6. Nebraska - Combined State and Local Tax Collections (in constant dollars per capita)

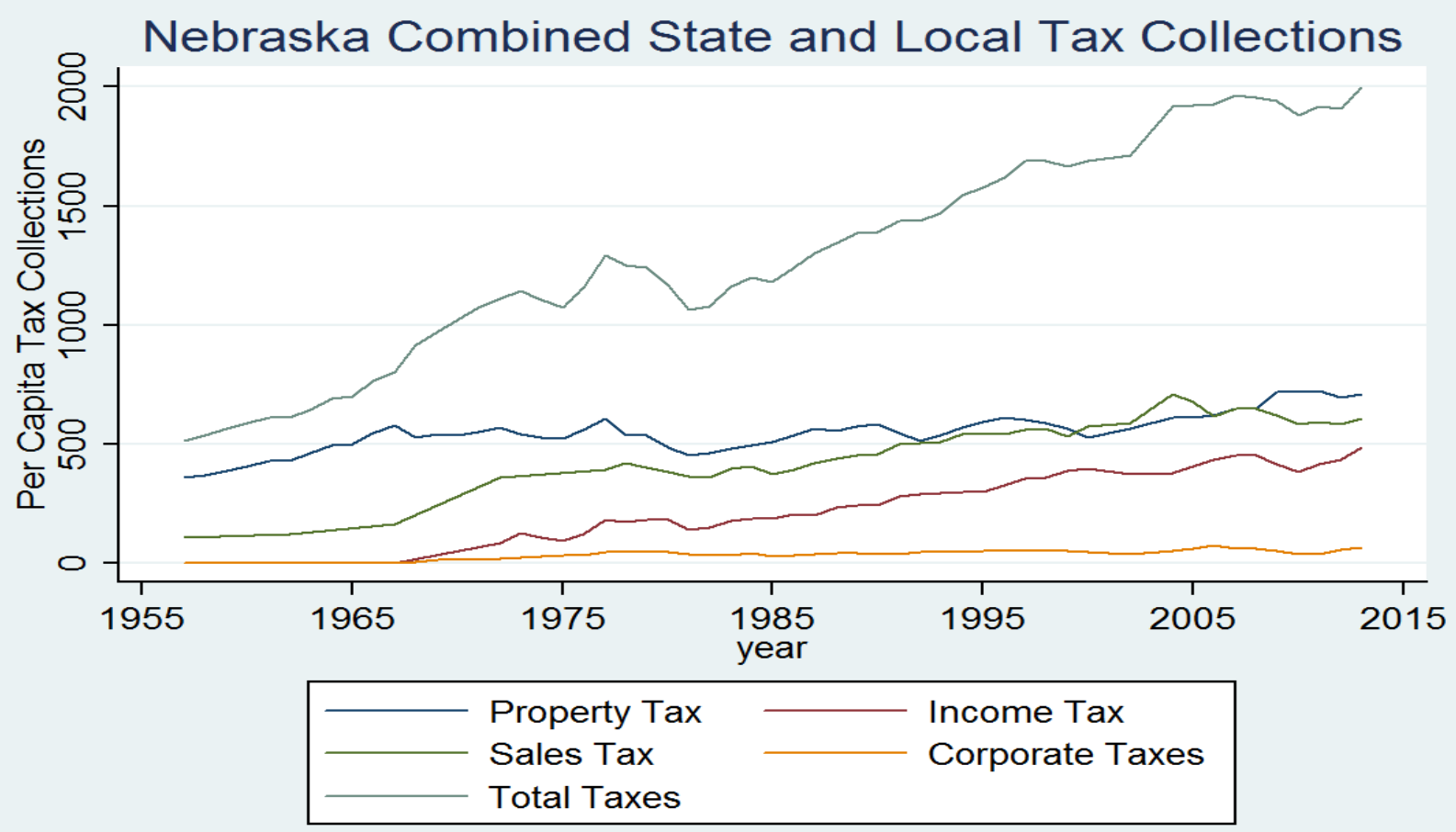

Source: U.S. Census Bureau Survey of State and Local Finances. 
Figure 7. Utah - Combined State and Local Tax Collections (in constant dollars per capita)

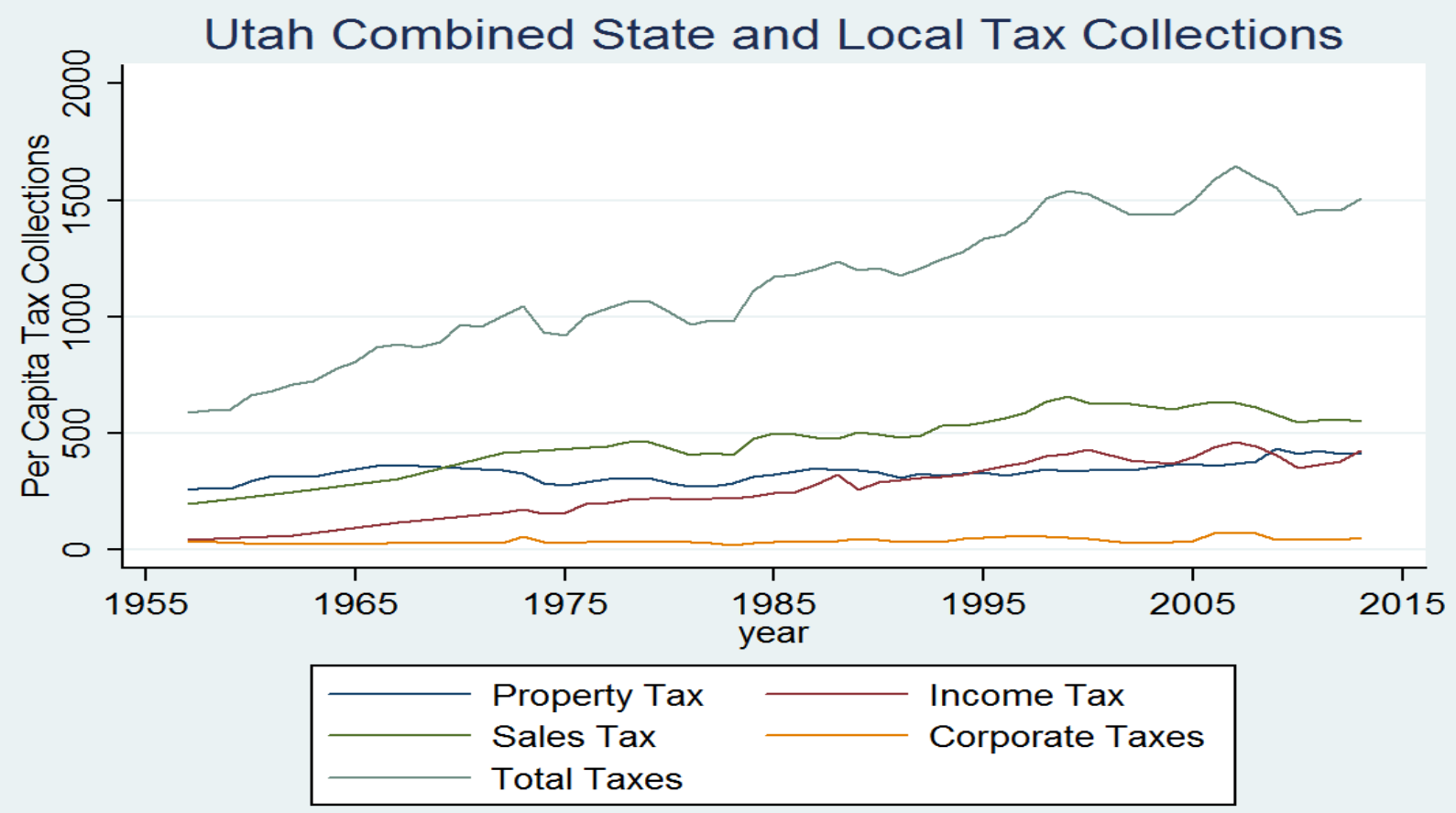

Source: U.S. Census Bureau Survey of State and Local Finances.

Figure 8. Louisiana - Combined State and Local Tax Collections (in constant dollars per capita)

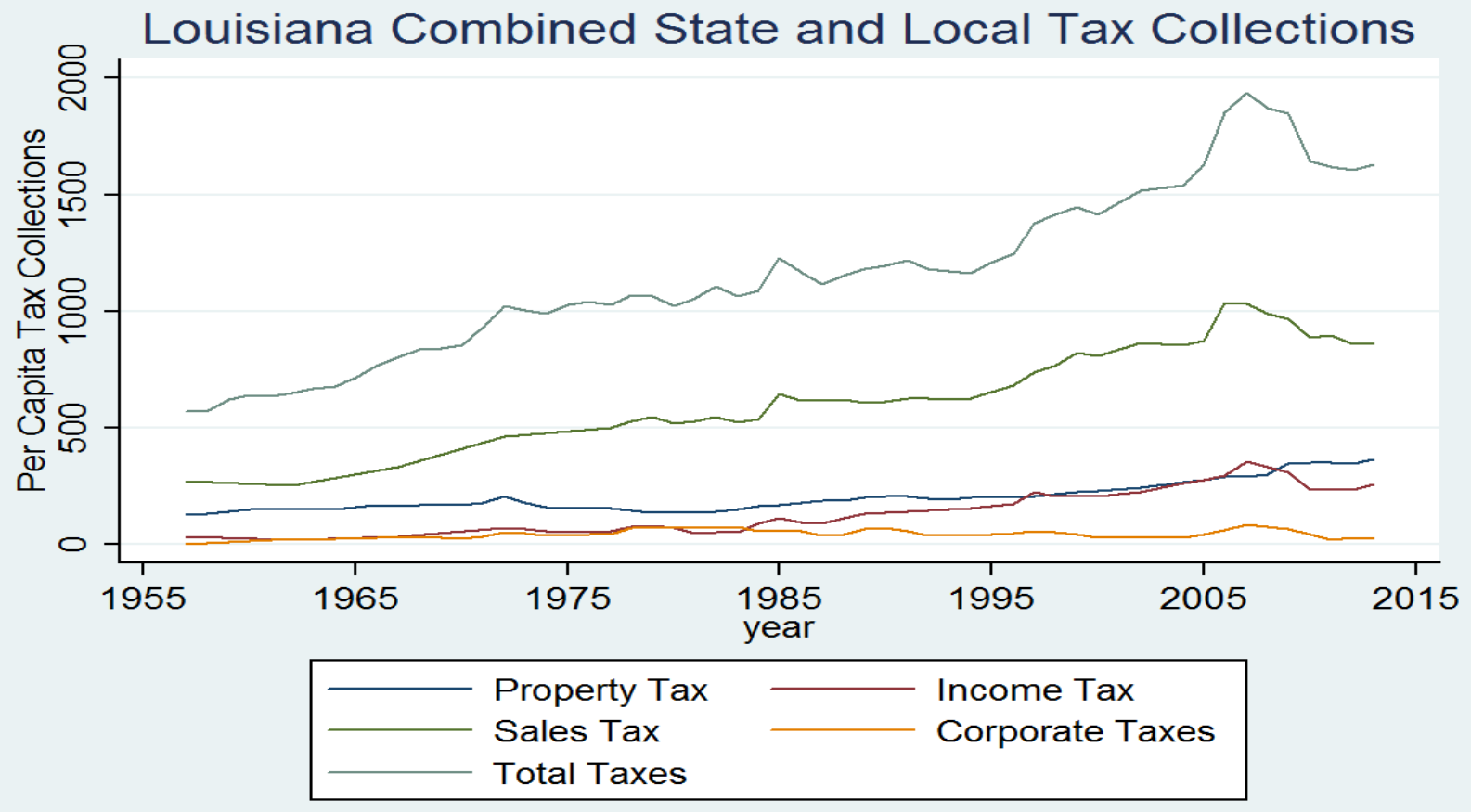

Source: U.S. Census Bureau Survey of State and Local Finances. 


\section{Endnotes}

${ }^{1}$ See Schanz (1896), Haig (1921), and Simons (1938) for detailed discussions.

${ }^{2}$ Along with the District of Columbia, these states include: Arizona, California, Connecticut, Florida, Georgia, Hawaii, Indiana, Kansas, Kentucky, Maine, Massachusetts, Minnesota, Nebraska, New Mexico, New York, North Carolina, North Dakota, Ohio, Oklahoma, Oregon, South Carolina, Tennessee, Utah, Virginia, Washington, and Wyoming. Louisiana has recently joined this group. See Bourdeaux (2011) and Pathak et al. (2016) for comprehensive discussions of these many reform efforts.

${ }^{3}$ See also Alm and Sheffrin (2013). 